\title{
Can Power Be Self-Legitimating? Political Realism in Hobbes, Weber, and Williams
}

Forthcoming in European Journal of Philosophy

Ilaria Cozzaglio (ilaria.cozzaglio@normativeorders.net)

Amanda R. Greene (a.greene@ucl.ac.uk)

\begin{abstract}
Political realists seek to provide an alternative to accounts of political legitimacy that are based on moral standards. In this endeavor, they face the challenge of how to interpret the maxim that power cannot be self-legitimating. In this paper we argue that work by Bernard Williams sheds light on the possible answers to this challenge. While Williams aligns himself with the realist tradition, his account of legitimacy contains an implicit critique of political realism. This is evident, we show, in his rejections of the views of Thomas Hobbes and Max Weber. Williams is not satisfied with Hobbes because he conflates legitimacy and political order, eliminating space for criticizing power. Weber's view, however, offers a non-moralist standard of legitimacy that has critical purchase. This critical purchase emerges from the demands made on rulers to uphold the values that underlie their legitimation, combined with the ethic of responsibility. The resulting grounds for criticism are thus consistent with the maxim that power cannot be self-legitimating - the very maxim that Williams puts at the heart of his realism. By showing that Williams's partial rejection of Hobbes and Weber cannot be sustained only on realist grounds, our analysis clarifies the limits of political realism.
\end{abstract}

\section{Introduction ${ }^{1}$}

Political realists challenge the idea that political theory is a matter of applying moral principles to the political context. There are distinctive problems raised by politics, they claim, that generate special standards of evaluation. The standards that apply to politics are special, they think, in the sense that they are not entirely dependent on universal moral principles. This stance sets political realists apart from political moralists, those who affirm that the principles that govern politics are derivable from the principles that govern morality.

\footnotetext{
${ }^{1}$ For helpful feedback and discussion, we would like to thank Alison McQueen and Steven Klein.
} 
But whenever political realists affirm that the political domain generates its own evaluative principles, a philosophical difficulty arises. The difficulty is that political realists need to identify principles of evaluation that go beyond a description of politics. Otherwise, the endeavor would be an exercise in empirical social science, rather than a normative theory of politics. In other words, defenders of political realism must articulate a special form of normativity that is unique to the political domain: it must not be reducible to moral principles, but it also must avoid mere description.

This difficulty becomes all the more striking when it comes to substantive theories of political legitimacy. Political realists, on the whole, reject the idea that moral requirements set the terms for political legitimacy. ${ }^{2}$ They are sometimes accused of equating political legitimacy with the acceptance of power by subjects, however that acceptance happens to be produced. According to this outlook, a system of political order may secure its own legitimacy through the effective use of power, including intimidation and manipulation. The upshot, someone might think, is that a particular regime comes to be legitimate whenever its subjects believe that it is legitimate. But such a view seems to eliminate the critical distance that is required for evaluating the exercise of political power, something that realists hope to maintain. To avoid a collapse into a merely descriptive account, realists need to say that power must fulfil some other standards in order to be legitimate. In other words, they must affirm the maxim that power cannot be self-legitimating. But how should we understand this maxim when there can be no recourse to moral standards?

\footnotetext{
${ }^{2}$ Political realism is a heterogenous family of views, but most of its defenders distinguish the evaluative standards of legitimacy from the demands of morality. Contemporary examples of political realists include (Williams, 2005; Geuss, 2008; Rossi, 2012; Sleat, 2013). For a comprehensive survey of approaches to political realism, including a taxonomy of the dimensions along which they vary, see (Rossi and Sleat, 2014). For historical discussion of the realist 'tradition', including the classical realists and structural realists in international relations theory, see (McQueen, 2016; McQueen, 2017).
} 
In this paper we take up the question of self-legitimating power by examining the views of political realism's latest advocate, Bernard Williams. ${ }^{3}$ Williams elaborates his realist view of legitimacy in terms of a legitimation demand (Williams, 2002; Williams, 2005). As we discuss below, what it takes to meet this demand is three-fold. First, there must be a solution to the first political question, which is the problem of how to eliminate the constant threat of violence. Second, this solution must "make sense" to subjects as an intelligible form of social order, where this depends on the actual perspectives of subjects in a given historical context. Third, the acceptance of a solution by subjects must not have been produced by the very same power that is being accepted - that is, a system of political power must not artificially bring about its own acceptance. Thus, for Williams, the descriptive facts about effective power come first. At the same time, he rejects the idea that power can simply manufacture its own acceptance in order to secure legitimacy. In short, Williams defends a theory of political normativity that stops short of full-blown morality. ${ }^{4}$ Since Williams is sensitive to the difficulty of avoiding both moralism and descriptivism, examining his view allows us to address the larger question of whether the political domain can be considered to produce its own norms, independently of the moral realm.

Williams's view has attracted critics and defenders, and the ensuing debate has focused largely on his critique of the liberal approach to legitimacy defended by Rawls. ${ }^{5} \mathrm{We}$ think that this emphasis has diverted attention from a critical question. While commenters debate whether realist legitimacy ought to unseat liberal legitimacy, they neglect a deeper issue with Williams's revival of political realism. The issue is that Williams lacks a

\footnotetext{
${ }^{3}$ Williams identifies as a realist, and is seen by many as such. For purposes of this paper we take this to be the case, though we recognize that some scholars disagree.

${ }^{4}$ Among his objections to moralism are its false opposition between principles and interests, its lack of historical sensibility, and its presumption that there are universal moral standards of acceptable government arising from Enlightenment morality (Williams, 2005, pp. 13-16). He insists that we need, instead, a political morality that affords "greater autonomy to distinctively political thought," though it is not entirely clear what he means (Williams, 2005, p. 3).

${ }^{5}$ For discussions of Williams's critique of liberalism, see (Bavister-Gould, 2011; Hall, 2013; Sleat, 2013; Waldron, 2013). For examples of articles explicitly comparing Williams with Rawls, see (Gledhill, 2012; Jubb, 2015).
} 
philosophical basis for rejecting the realist theories of political legitimacy that have been expounded already by others. Here we are thinking chiefly of the realist accounts that can be found in Thomas Hobbes and Max Weber.

Williams is naturally drawn to both Hobbes and Weber. He hopes to establish politics as an evaluative sphere that is distinct from morality more broadly. This hope leads him towards a standard of legitimacy that is focused on peace and security (following in the footsteps of Hobbes) and at the same time, is keyed into the perspectives of subjects in different historical circumstances (following in the footsteps of Weber). Thus Williams adopts elements of Hobbes and Weber in his realist account - indeed, this adoption is chiefly what enables him to avoid moralism. But in the end, Williams rejects key aspects of their positions, suggesting that he is a critic of realism as well as of moralism. In light of these observations, we pose this question: if Williams's goal is to leave moralism behind and instead advance a realist account of political legitimacy, what is wrong with the Hobbesian and Weberian versions? On what grounds can he justify rejecting them? Answering this question, we think, reveals and sharpens a key problem in the realist approach - how to understand the potential of power to be self-legitimating.

Our focus, then, will be on this question: how should a political realist interpret the claim that power cannot be self-legitimating? Williams's hope of developing an answer to this question requires him to address two challenges. One is to find principled grounds for resisting Hobbes's view that a system of subjection to a sovereign entails political legitimacy. The second challenge is to find principled grounds for resisting Weber's view that legitimacy is secured whenever there is widespread belief in the validity of a system of obedience. Williams finds these views inadequate, but not for reasons arising from political moralism. Our aim in this paper is to assess these two rejections when they are made - as Williams claims - from a vantage point that is internal to political realism. 
In what follows, we unearth Williams's implicit critique of the political realism that can be found in Hobbes and Weber. Along the way, we explain the costs that are incurred by Williams when he rejects their views, highlighting why Williams -- and others attracted to realism -- might nevertheless want to incur these costs. For Hobbes, political legitimacy is conceptually bound up with the idea of a political relationship between subjects and their sovereign, a relationship in which obedience is exchanged for protection. While Williams agrees that establishing civil order is essential to the definition of a political relationship, he is unsatisfied with Hobbes's lack of a distinction between securing peaceful order and securing legitimacy. So, we argue, Williams departs from Hobbesian realism because the concepts of political legitimacy and mere political order are effectively equivalent. This shortcoming creates pressure for Williams to adopt instead the realism that is advanced by someone like Weber, who distinguishes between legitimate and illegitimate political domination.

Turning next to Weber, we show that Williams follows Weber in defining legitimacy in terms of the beliefs of individual subjects. For Weber, we argue, a mere political order fails to be legitimate whenever obedience is not based on a belief among subjects in the validity of power. Thus, we explain, the distinction between legitimacy and mere order that was lacking in Hobbes is available in Weber. However, Williams does not avail himself of Weber's solution because, apparently, it is insufficient for criticizing the abuse of power. At this point, we develop a response on Weber's behalf by identifying two dimensions of normative evaluation in his account of legitimate political domination: an ethic of rule and an ethic of responsibility. Despite these realist forms of political normativity, Williams does not adopt Weber's approach. Instead, Williams adds a critical theory proviso to the legitimation demand, a proviso that he derives from the political axiom that "power cannot be selflegitimating.' We show that Weber would also affirm this axiom, though differing in its interpretation. We conclude that Williams has no realist basis for rejecting Weber's 
interpretation of this claim and, therefore, no realist basis for rejecting Weber's account of legitimacy.

The upshot of the paper is to call into question the advantages of Williams's formulation of political realism, as compared to that of Hobbes and Weber. Since Weber's account adequately addresses Williams's dissatisfaction with Hobbes, while at the same time retaining scope for the normative evaluation of power, Williams lacks a basis for rejecting Weberian realism. At the same time, we argue, if Williams were to amend Weberian realism in order to provide more scope for criticizing power, this would lead him back in the direction of Hobbes. While Williams is clearly dissatisfied with both of those options, he lacks grounds within his own realist framework to show why his alternative is superior. In closing, we draw out the implications for political realism.

\section{Williams and Hobbes}

Williams explicitly draws on Hobbes in order to construct his realist theory of legitimacy. He identifies in Hobbes a characterization of politics as a solution to the threat of violent conflict that is always present in human groups. Williams says: "I identify the 'first' political question in Hobbesian terms as the securing of order, protection, safety, trust, and the conditions of cooperation. It is logically 'first' because solving it is the condition of solving, indeed posing, any others" (Williams, 2005, p. 3). Williams thus aligns himself with Hobbes by defining politics in terms of solving the problem of order. Moreover, Williams reads Hobbes as saying there is a close connection -- equivalence, even -- between establishing a commonwealth and securing political legitimacy: "[Hobbes thought] that the necessary condition of LEG was also the sufficient condition of it" (Williams, 2005, p. 3). 
We agree with Williams's reading of Hobbes, more or less. ${ }^{6}$ But we want to examine Hobbes's view more closely, in order to clarify exactly where Williams rejects his account. Following Robin Douglass, we take legitimacy in Hobbes to be "the grounds for some person or body having the authority to rule" (Douglass, 2016, p. 3). For our purposes, the key passages are those in which Hobbes speaks of legitimacy explicitly, as well as those in which he argues that sovereignty arises from authorization. We begin with the latter.

Hobbes contrasts life lived under a sovereign in a commonwealth with life outside of a commonwealth. In Leviathan, he argues that as long as individuals are outside of a commonwealth, they face the ever-present prospect of a violent death, due to their equal hopes and equal vulnerability to each other $\left(L\right.$ xiii.1-9). ${ }^{7}$ Since the state of nature involves the ongoing fear of violent death, according to Hobbes, individuals should create a political order through the establishment of a sovereign. The result is a system of subjection in which obedience is exchanged for protection, and establishing this system necessarily involves a group of people being united under the same common power. Hobbes argues that individuals establish a civil state through a procedure that unifies their will and authorizes a sovereign. He says, "The only way to erect such a Common Power... is to conferre all their power and strength upon one Man, or upon one Assembly of men, that may reduce all their Wills, by plurality of voices, unto one Will, ....and every one to owne and acknowledge himself to be Author of whatsoever he that so beareth their Person, shall Act, ...and therein to submit their Wills, every one to his Will, and their Judgments, to his Judgment" ( $L$ xvii.13). Therefore,

\footnotetext{
${ }^{6}$ It should be noted, however, that Hobbes's realism does not exhibit the total autonomy of political normativity that Williams seems to be seeking. In his thorough examination of political realism in Hobbes, Robin Douglass argues that "those who attribute an autonomy of the political position to Hobbes downplay the importance he attached to peace as a pre-political moral value, which calls into question the political-moral demarcation that realism relies upon" (Douglass, 2016, p. 2). Although we lack the space to discuss morality in Hobbes, we intend for our analysis to be consistent with this observation.

${ }^{7}$ For a discussion of equal vulnerability in Hobbes, see (Hoekstra, 2012). All references to Leviathan are to the English version (Hobbes, 1991); citations are according to chapter and paragraph number.
} 
Hobbes characterizes a commonwealth as a system of subjection in which obedience is exchanged (successfully) for protection through a process of authorization.

For Hobbes, any society apart from a commonwealth is not a political condition, properly speaking. A commonwealth is a system of subjection to a sovereign, and he calls this system a civil condition so as to contrast it with the state of nature. ${ }^{8}$ In fact, the label of "political" occurs in De Cive and Leviathan only in order to characterize the civil state. ${ }^{9}$ For example, individuals are called citizens only when they establish a sovereign; prior to that, Hobbes refers to them as a mere "Multitude" $\left(L\right.$ xvii.4). ${ }^{10}$ Furthermore, he repudiates the classical Greek notion that political organization is natural, as opposed to artificial. ${ }^{11}$ Thus it can be inferred that whatever is outside the civil state of a commonwealth should not be considered a political condition at all. This view resonates with Williams's remark that "solving [the problem of Hobbesian order] is the condition of solving, indeed posing, any other [political questions]" (Williams, 2005, p. 3).

We now turn to the passages in which Hobbes speaks explicitly of legitimacy. The term is used occasionally, though never defined. He normally uses it to refer to contracts,

\footnotetext{
${ }^{8}$ The view that there is a radical difference in Hobbes between the state of nature and the civil state is shared by most scholars, though explained in varying ways. For example, James Read interprets it through the concept of power, which would change "its nature... from natural to artificial" (Read, 1991, p. 507). Martin Loughlin stresses the rational process that leads the multitude from the state of nature to the civil state: "the state was brought into existence through the exercise of political reasoning” (Loughlin, 2012, p. 8).

${ }^{9}$ For example, he says in De Cive: “...there are two kinds of commonwealths: one kind is natural, like the Paternal and Despotic; the other is the kind of commonwealth which is by design [institutivum], and which may also be called political" (Hobbes, DC v.12). All references to De Cive are to chapter and article number, following Warrender's edition in Latin (Hobbes, 1983) and Tuck and Silverthorne's edition in English (Hobbes, 1998).

${ }^{10}$ Quentin Skinner emphasizes the covenant that authorizes the sovereign as the means through which a multitude becomes "a people" and enters into a relationship with the sovereign. He says, "when the members of the multitude authorise a man or assembly to serve as their representative, the effect is to transform them from a mere aggregation into one Person because they are now endowed with a single voice" (Skinner, 2005, p. 177). Loughlin also underlines the co-creation of the sovereign and the people, saying that " 'the people', as distinct from 'the multitude', came into existence as a result of the pact to create the sovereign" (Loughlin, 2012, p. 10). For further discussion of how the multitude achieves unity through incorporation and then impersonation, see (Pettit, 2009, pp. 72-75).

${ }^{11}$ In Leviathan he rejects Aristotle's assertion that we are political animals ( $L$ xvii), and in De Cive he says, "Yet their swarms are still not commonwealths [civitates], and so the animals themselves should not be called political..." (DC v.5).
} 
promises, and marriage, implying that whatever is lawful is legitimate. ${ }^{12}$ There are two passages in which Hobbes explicitly speaks of the sovereign as legitimate, and they both pertain to the authorization procedure involved in establishing a commonwealth. In De Cive, he claims that a person "becomes a legitimate Monarch [legitimus fit Monarcha] if he receives the consent of the people; without that consent, he is not a Tyrant, but a public enemy [hostis]" (DC vii.3). ${ }^{13}$ This claim follows, it would seem, from an explanation of the role played by consent in unifying a multitude and conferring authority on the sovereign: "Sovereign power, then, is established by force of the agreements into which individual subjects or citizens mutually enter one with another; and all agreements get their force from the will of the contracting parties, and likewise may lose their force and be dissolved by consent of the same parties" (DC vi.20). ${ }^{14}$ In Leviathan, he further explains that this authorization mechanism involves a unification of each person's will into the sovereign representative will. ${ }^{15}$ We call this an authorization mechanism because it is presented as the grounds for a sovereign coming to have authority, where this is more than just the systematic ability to exercise force. Therefore, the authorization mechanism is not only the cause but also the normative explanation of sovereignty, as Hobbes constructs it.

\footnotetext{
${ }^{12}$ For example, Hobbes says in Leviathan that "...the teaching that matrimony is a sacrament giveth to the clergy the judging of the lawfulness of marriages; and thereby, of what children are legitimate; and consequently, of the right of succession to hereditary kingdoms" ( $L$ xlvii.9). In De Cive he says, "What is to count as a theft on the part of a citizen or as murder or adultery or a wrongful act is to be determined by the civil, not the natural, law... not every act of intercourse is adultery, but only what the civil laws forbid... the breaking of a promise is a wrong, when the promise itself is legitimate [licitum est]; but where there is no right $[i u s]$ to make an agreement, no right [ius] passes; hence no wrong [iniuria] follows" (DC vi.16).

${ }^{13}$ This statement occurs in a comparison of monarchy and tyranny in which Hobbes says, "They differ only in the way they exercise power... [O]nce a king is legitimately established in sovereign power, the citizens will feel that he should be called King, if he is viewed as exercising his power well; if not, he will be seen as a Tyrant" (DC vii.3). For further discussion of Hobbes on tyranny, see (Hoekstra, 2001).

${ }^{14} \mathrm{He}$ confirms the connection between consent and authority when he continues, "By no stretch of the imagination could it ever happen that all the citizens together would unite in conspiracy against the sovereign power, without one single exception. There is therefore no danger that sovereigns can be rightly stripped of their authority" (DC vi.20).

${ }^{15}$ He says, "A Multitude of men are made One Person, when they are by one man, or one Person, Represented; so that it be done with the consent of every one of that Multitude in particular... Unity, cannot otherwise be understood in Multitude" ( $L$ xvi.13).
} 
Therefore, we read Hobbes as saying that political subjection to a sovereign is legitimate because of the mechanism by which it is created. ${ }^{16}$ This is confirmed by the second occurrence of the term "legitimate" pertaining to sovereign power. In De Cive, Hobbes considers the question of whether the legislator is known to all citizens. He argues that he must be known to each, either explicitly or implicitly: “...Without his personal consent and agreement, either explicit or implied, the right of legislation [ius legislationis] could not have been conferred on anyone... if it is not explicit, it must at least be implied, as when they accept the benefit of a person's power and laws for protection and preservation of themselves against others" (DC xiv.12). ${ }^{17}$ Thus it is the implicit recognition of the exchange of obedience for protection that explains the sovereign's right to legislate. He says, “...for when we demand that our fellow citizens obey someone's power for our good, we admit by that very demand that his power is legitimate [imperium legitimum esse]" (DC xiv.12) ${ }^{18}$ Therefore, in this passage, Hobbes's use of 'legitimate' supports the interpretation that authorizing the sovereign both establishes that sovereign power exists and, at the same time, serves to explain why it is legitimate.

On this reading of Hobbes, the very existence of a commonwealth depends on an authorization procedure that, in turn, secures legitimacy. ${ }^{19}$ Thus there simply cannot

\footnotetext{
${ }^{16}$ A manifestation of the sovereign's legitimacy is his normative power to issue commands. Once the sovereign is created, he has the right to decide what is wrong and what is right, and citizens have an (almost absolute) duty to obey. For further discussion, see (Pettit, 2009, pp. 125-129) and (Sreedhar, 2010).

${ }^{17}$ The sentence begins by identifying how the right of legislation comes to be conferred: "Cognitio legislatoris dependent ab ipso ciue; nam sine consensu \& pacto suo proprio, vel expresso, vel subaudito ius legislationis conferri in neminem potuit." The following sentences elaborate on the two kinds of consent, saying this of implicit consent: “...vel saltem subaudito, ut quando utuntur beneficio emperii, \& legume alicuius, ad protectionem \& conseruationem sui aduersus alios" ( $D C$ xiv.12).

${ }^{18}$ The full sentence: "Cuius enim imperio conciues nostros obedire postulamus bono nostro, illius imperium legitimum esse, ea ipsa postulation confitemur" ( $D C$ xiv.12).

${ }^{19}$ Douglass remarks that "Hobbes's emphasis on contract and consent, however, might seem like an unpromising way of theorising legitimacy from a realist perspective", thereby confirming our interpretation of legitimacy in Hobbes (though he challenges the classification of Hobbes as a realist) (Douglass, 2016, p. 3).
} 
be stable political order without political legitimacy. ${ }^{20}$ In light of this, one could say that for Hobbes, a system of political order is defined as a social arrangement in which Williams's "first political question" has been solved through an authorization procedure that establishes the sovereign. At the same time, the authorization mechanism satisfies the conditions for political legitimacy, since it establishes the sovereign's right to rule. Since the concepts of legitimacy and political order are defined in terms of each other, it is easy to see how the standard of political legitimacy depends on the value of securing political order, as opposed to drawing on a moral standard that goes beyond stable order. This tight connection between securing order and securing legitimacy is an element of Hobbes that Williams finds appealing.

\subsection{Williams's rejection of Hobbesian Realist Legitimacy}

No sooner has Williams affirmed a key part of Hobbes than he departs from it. He begins by announcing one motivation for the departure:

If one disagrees with Hobbes, and thinks that more than one set of political arrangements, even in given historical circumstances, may solve the first question, it does not strictly follow that the matter of which arrangements are selected makes a further contribution to the question of LEG, but it is entirely reasonable to think that this can make a contribution, and that some, but only some, of such arrangements are such that the state will be LEG. Someone who disagrees may merely be disagreeing with Hobbes on this point. (Williams, 2005, p. 3)

The language of "further contribution" implies the following picture of legitimacy:

Hobbesian order makes some initial contribution, while other factors make a further contribution. For, if only some regime types that secure order also achieve legitimacy, then the implication is that other regimes achieve order but not full legitimacy. ${ }^{21}$ Thus Williams

${ }^{20}$ Pettit likens the definitional connection between sovereignty and legitimacy to Hobbes's discussion of constructing a circle with a compass: "When we learn how to construct a circle, as we decide to name the construct, we build up a definition of the circle and its related elements that encodes the properties ensured by that mode of construction... The same, in Hobbes's view, will be true of the commonwealth" (Pettit, 2009, pp. 116-119)

${ }^{21}$ Williams indicates that he thinks that legitimacy is roughly a matter of degree: 'We can accept that the considerations that support LEG are scalar, and the binary cut LEG/ILLEG is artificial and needed only for certain purposes' (Williams, 2005, p. 10). 
casts doubt on the following Hobbesian logic: the necessary conditions of a legitimate political relationship are "so demanding" that, because they entail very specific political arrangements, they also serve as the sufficient conditions (Williams, 2005, p. 3). Here Williams is alluding to Hobbes's argument that certain constitutional features are entailed by the need for a sovereign that is strong enough to guarantee protection (for instance, no separation of powers). In sketching out this route of departure, Williams seems to have in mind those who would defend other necessary conditions for legitimacy, such as democracy. Williams rejects this stance because it is a form of "political moralism.",22

Williams wants to stay in the political realism camp, and so he pursues a different sort of departure from Hobbes. According to Williams, the mere fact that a political system provides Hobbesian order is not enough to entail its legitimacy. On what basis does Williams reject this aspect of Hobbes? The answer cannot be that a regime has further imperatives beyond the one of providing order and security, such as promoting autonomy or respecting rights. Williams, as well as other political realists, must avoid such Enlightenment morality and instead extract a standard of legitimacy only from the idea of political order. Therefore, Williams must find something contained within the idea of establishing order that allows space for different ways of performing that task, only some of which lead to legitimacy. He does this by making several moves that constitute internal critiques of political realism - or so we will argue. In what follows we assess the first move: privileging the perspective of subjects.

\subsection{Williams's Realist Political Legitimacy}

Williams hopes to distinguish legitimacy from mere political order by requiring that it "make sense" to subjects in a given historical context. He calls this the Basic Legitimation

\footnotetext{
${ }^{22}$ Williams designates these concerns as one of "two different sorts of consideration" that might motivate someone to disagree with Hobbes (Williams, 2005, p. 3). He is interested in the other sort of consideration.
} 
Demand. He says, "Meeting the BLD is what distinguishes a LEG from an ILLEG state [...and] can be equated with there being an 'acceptable' solution to the first political question" (Williams, 2005, p. 4). For Williams, the Basic Legitimation Demand has been met when a justification of political power has been offered that is acceptable to each subject. ${ }^{23}$ What he means by acceptable is whether the justification "makes sense (MS)" given the historical conditions. He says, “A given historical structure can be (to an appropriate degree) an example of the human capacity to live under an intelligible order of authority... It makes sense (MS) to us as such a structure" (Williams, 2005, p. 11). Williams uses 'making sense as intelligible order' (MSIO) as a technical term, then; it is designed to capture the way in which categories of historical understanding determine whether a particular solution to the first political problem counts as acceptable. In other words, a given political arrangement is held to be acceptable whenever it makes sense (presumably, because it makes sense). Williams claims that a criterion involving this notion of "making sense" is "evaluative... [but] not normative" (Williams, 2005, p. 11). ${ }^{24}$

To make good on this framework, Williams needs a definition of mere political order that does not automatically entail legitimacy. We refer to mere political order -- here and in what follows -- as "political subjection," a situation in which Hobbesian order has been secured through a stable system of obedience. According to Williams, this subjection obtains whenever the first political question has been solved and there is a claim of authority, understood as the expectation of obedience to commands. Williams describes it as follows:

A coerces B and claims that B would be wrong to fight back: resents it, forbids it, rallies others to oppose it as wrong, and so on. By doing this, A claims that his actions transcend the conditions of warfare, and this gives rise to a demand for justification of what A does. When $\mathrm{A}$ is the state, these claims constitute its claim of authority over B. (Williams, 2005, p. 6)

\footnotetext{
${ }^{23}$ He says, "The claim is that we can get from the BLD a constraint of roughly equal acceptability (to each subject)..." (Williams, 2005, p. 7). The phrase introduces a problematic ambiguity, as discussed and clarified in (Hall, 2015, pp. 471-473).

${ }^{24}$ It is hard to know what Williams means by 'evaluative,' though he would deny that it is prescriptive. He suggests the following translation principle: "what they do makes sense if it would make sense to us if we were them" (Williams, 2005, p. 11). He adds a proviso that is inspired by critical theory, which we discuss below.
} 
For Williams, the demand for legitimation arises when a person claims that they must be obeyed by a group of subjects. This leads us to infer that a claim of authority, combined with the securing of Hobbesian order, is sufficient for political subjection but not for legitimacy.

Thus for Williams, securing Hobbesian order is merely the trigger for a demand of legitimation, not the sufficient condition. Legitimacy, on the other hand, is the acceptable exercise of power, where such acceptability depends on the justification meeting the standard of "making sense as intelligible order," relative to a historical context. On this basis, Williams thinks, he can adequately distinguish the two concepts, thereby avoiding the conceptual equivalence of Hobbesian realism.

\subsection{Distinguishing Legitimacy from Political Subjection}

Williams apparently thinks that he has avoided the conceptual equivalence of Hobbesian realism, but in fact, things are more complicated. This is because, in aiming to take some -- but not all -- of Hobbes, Williams has subtly shifted the political problem of order. We can see this by distinguishing two kinds of threats to security: those coming from other subjects, which we might call horizontal, and those coming from the sovereign, which we might call vertical. According to Williams, a solution to the first political question does not count if the solution recreates the problem (Williams, 2005, p. 4). When he describes this as a reign of terror, it is evident that a solution must include the problem of vertical as well as horizonal security. But for Hobbes, the introduction of vulnerability with respect to the sovereign is simply the necessary means for the sovereign to provide security with respect to other threats. ${ }^{25}$ In fact, Hobbes accepts sovereignty by conquest, in which a new sovereign intimidates subjects into accepting his rule:

\footnotetext{
${ }^{25}$ To be fair, Hobbes does not ignore the threat deriving from absolute power, and he allows disobedience in certain cases, including if the monarch asks citizens to die $(L)$ \{Hobbes, 1994, 142\}. When
} 
A commonwealth by acquisition is that where the sovereign power is acquired by force; and it is acquired by force when men singly (or many together by plurality of voices) for fear of death or bonds do authorize all the actions of that man or assembly that hath their lives and liberty in his power. And this kind of dominion or sovereignty differeth from sovereignty by institution only in this, that men who choose their sovereign do it for fear of one another, and not of him whom they institute; but in this case they subject themselves to him they are afraid of. In both cases they do it for fear... $(L \text { xx.2 })^{26}$

Thus for Hobbes, sovereignty by acquisition (conquest) is legitimate. This is because the relevant acceptance by subjects can be imputed, on the basis of its being a necessary part of the relationship of political subjection. But Williams himself does not approve of achieving legitimacy through intimidation. Therefore, the standard of legitimacy that Williams relies on has to be something more than whatever form of tacit acceptance is implicitly correlative with stable order. ${ }^{27}$

As long as Williams holds that achieving order through fear and intimidation does not amount to legitimacy, he must depart from Hobbes. ${ }^{28}$ As things stand now, his attempt to cash this out in terms of the perspective of subjects risks the sort of conceptual equivalence that we have seen in Hobbes. But this puts Williams in a difficult position. In order to avoid moralism, Williams must defend the idea that the normative gap that opens up when he

Hobbes discusses the "liberty of subjects", liberty is defined in such a way that it does not constrain the sovereign's right to command, since it consists in the freedom to do all those things on which the law is silent ( $L$ ) \{Hobbes, 1994, 138-9\}. For a discussion of disobedience in Hobbes, see (Sreedhar, 2010).

${ }^{26}$ Hobbes famously distinguishes a commonwealth by acquisition from a commonwealth by institution ( $L$ xvii). Our argument holds in spite of this distinction. For even if we limited the definition of political subjection so that it only applied to sovereignty by institution, we could make a parallel argument. For Hobbes, it is part of the concept of political subjection that the relevant authorization is in place, in such a way that legitimacy is thereby secured. For an argument that the differences between sovereignty by institution and acquisition do not affect the creation of the sovereign through an authorization mechanism, see (Pettit, 2009, pp. 117-118).

${ }^{27}$ Someone might say, on Williams's behalf, that the legitimacy standard is implicitly contained within the relationship of political subjection by claiming that tacit acceptance can be presumed whenever there is a stable solution to the first political question. Thus the relevant acceptance just comes along with political subjection, once it has been suitably understood. Another claim one might make on Williams's behalf is that political legitimacy is instantiated in the actual world in all and only those circumstances where there is also political subjection. So, while "peaceful order" and "legitimacy" mean different things in theory, they always coincide in practice, for all intents and purposes. However, neither of these elaborations will work because, if successful, they rule out the possibility of illegitimate politics in the real world -- a possibility Williams wants to hold on to. It would imply that as soon as legitimacy is compromised, so is political order itself, leading to a Hobbesian state of nature. For further discussion, see (Greene, “The Promise of Political Realism", unpublished manuscript).

${ }^{28}$ This suggests that Williams and Hobbes actually have different ideas about the fundamental problem to be solved by politics, though Williams is not as forthcoming about this as he could be. 
departs from Hobbes is governed only by standards that emerge from the relationship of political subjection. Williams claims that his standard of political legitimacy emerges entirely from the definition of political subjection -- indeed, he stakes his realist credentials on it (Williams, 2005, p. 8). But it is difficult to clearly state this idea -- much less defend it -without falling back into the Hobbesian form of realism. Ultimately, Williams needs to depart more definitively from Hobbes's account. We think that he ought to look at the resources available in Weber.

\section{Weber's Realist Political Legitimacy}

What Williams needs, and what he could extract from Weber, is a theoretical framework for distinguishing between political legitimacy and political subjection (“domination" or "rule", in Weber's terminology). ${ }^{29}$ According to Weber, there is a clear theoretical category of illegitimate domination. This category allows him to avoid collapsing the concepts in two ways. First, there can be legitimate but non-political domination (e.g. a religious hierarchy). ${ }^{30}$ Second, and more important for present purposes, there can be domination that is political but illegitimate. In fact, we argue that Weber develops the idea of illegitimate political domination in a way that has normative implications (in a qualified sense, to be explained below), while nevertheless remaining realist in the sense that Williams prizes. Thus Weber's account could furnish Williams with the non-moralist grounds that he needs for departing from Hobbes. However, Williams rejects Weber's account of legitimacy by introducing a proviso that power cannot produce its own acceptance. This proviso is

\footnotetext{
${ }^{29}$ We are following the common practice of rendering Herrschaft as "domination," though we prefer "rule." According to Weber, domination "does not include every mode of exercising 'power' or 'influence' over other persons"(Weber, 1978, p. 212).

${ }^{30}$ Weber gives several examples of non-political group domination, e.g. the subjection of factory employees to their employer, or vassals to a feudal lord, even when both of these relations are entered into freely (Weber, 1978, pp. 213-214).
} 
another internal critique of political realism advanced by Williams. In what follows we will look at Weber more closely in order to assess this internal critique. Ultimately we will argue that Williams lacks adequate justification for departing from Weberian political realism.

\subsection{Weber on Legitimate Domination}

Weber defines domination as "the probability that a command with a given specific content will be obeyed by a given group of persons" (Weber, 1978, p. 53). ${ }^{31}$ For Weber, what marks off legitimate from illegitimate domination is the quality of the obedience. He explains that there are different types of obedience: "Domination... may be based on the most diverse motives of compliance: all the way from simple habituation to the most purely rational calculation of advantage " (Weber, 1978, p. 212). In fact, Weber acknowledges explicitly that obedience is sometimes sustained through brute force: "the political community is so constituted that it imposes obligations on the individual members which many of them fulfil only because they are aware of the probability of physical coercion backing up such obligation" (Weber, 1978, p. 903).

However, Weber contrasts obedience based on calculations of advantage or fear with obedience based on beliefs about the rightfulness of the authority. He calls the latter "belief in legitimacy", and he notes that it provides a more stable basis for domination than "purely material interests and calculations of advantages" (Weber, 1978, p. 213). Weber claims that whenever the obedience is not tied to material interests or advantages, it is tied to a belief in legitimacy: "So far as it is not derived merely from fear or from motives of expediency, a willingness to submit to an order imposed by one man or a small group, always implies a

\footnotetext{
${ }^{31}$ Weber's concept of domination applies at the simplest level to individual relations of command and obedience. He says, "The existence of domination turns only on the actual presence of one person successfully issuing orders to others" (Weber, 1978, p. 53). However, here we will focus on group domination.
} 
belief in the legitimate authority" (Weber, 1978, p. 37). ${ }^{32}$ He says that, although the content of the belief varies, the obedience always rests on the perceived validity of the domination that is being exercised (Weber, 1978, p. 215). Accordingly, when a system of domination secures obedience on some other basis besides the belief in the validity of power, then we have illegitimate political domination. While systematic obedience is a necessary feature of political domination, it does not contribute to the legitimacy of the domination if it is grounded on fear or expediency. Thus, Weber's capacity to distinguish between multiple grounds of obedience provides the sought-after distinction between legitimate and illegitimate political order.

With this distinction in hand, it is possible to say a bit more about "belief in the validity of power." ${ }^{, 3}$ Weber describes this validity in terms of how subjects relate to commands:

"[Legitimate] domination will thus mean the situation in which the manifested will (command) of the ruler or rulers is meant to influence the conduct of one or more others (the ruled) and actually does influence it in such a way that their conduct to a socially relevant degree occurs as if the ruled had made the content of the command the maxim of their conduct for its very own sake. Looked upon from the other end, this situation will be called obedience." (Weber, 1978, p. 946) ${ }^{34}$

${ }^{32}$ In the original version, the quotation in the main text says "Die Fügsamkeit gegenüber der Oktroyierung von Ordnungen durch Einzelne oder Mehrere setzt, [...] den Glauben an eine in irgendeinem Sinn legitime Herrschaftsgewalt [...] voraus" (Weber, 2005, p. 27). The German better renders the sense of indeterminacy attached to legitimacy, i.e., legitimacy in an indeterminate sense.

${ }^{33}$ For simplicity, we will refer to the basis of obedience across all three types in this generic way. Note that Weber does not employ the word "belief" when describing the charismatic type, relying instead on notions of fascination and identification. However, on the generic level, he continues to speak of belief in legitimacy.

${ }^{34}$ It is evident that Weber is speaking of legitimate domination here, rather than mere domination because he says, "In the following discussion we shall use the term domination exclusively in that narrower sense which excludes from its scope those situations in which power has its source in a formally free interplay of interested parties... domination shall be identical with authoritarian power of command..." (Weber, 1978, p. 946). Weber sometimes uses the term autorität, but to avoid terminological confusion, we refrain from using the words authority and legitimacy in the very definition of legitimate domination. 
Elsewhere he describes this obedience as a situation where "the command is accepted as a valid norm." ${ }^{, 35}$ Thus Weber defines legitimate domination as obedience in which there is systematic acceptance of commands as valid. ${ }^{36}$

To complete the picture of Weber's legitimate domination, we need to look at what Weber calls the three "pure types" (Weber, 1978, p. 215). They all represent situations where commands are accepted as valid:

There are three pure types of legitimate domination. The validity of the claims to legitimacy may be based on:

1. Rational grounds - resting on a belief in the legality of enacted rules and the right of those elevated to authority under such rules to issue commands (legal authority)

2. Traditional grounds - resting on an established belief in the sanctity of immemorial traditions and the legitimacy [Legitimität] of those exercising authority under them (traditional authority); or finally,

3. Charismatic grounds - resting on devotion to the exceptional sanctity, heroism or exemplary character of an individual person, and of the normative patterns or order revealed or ordained by him (charismatic authority). (Weber, 1978, p. 215)

These ideal types of legitimate domination do not have a normative status in the sense of objective morality; rather, they are explanatory models of the bases on which systematic obedience is secured in a stable way. ${ }^{37}$ Note that these three models can be thought of as hermeneutical categories that derive from the interpretative task of the sociologist. Weber himself maintains that people may not be aware of the connection between one of these three models and their own actual belief in the validity of power (Weber, 1978, p. 38).

To sum up, in Weber's account it is possible to distinguish the concepts of political legitimacy and domination (what we call political subjection). Political legitimacy is

\footnotetext{
${ }^{35}$ He says, "The merely external fact of the order being obeyed is not sufficient to signify domination in our sense; we cannot overlook the meaning of the fact that the command is accepted as a 'valid' norm" (Weber, 1978, p. 946); "Des Befehls [...] seines Hingenommenwerdens als einer 'geltenden' Norm" (Weber, 2005, p. 695). "Hingenommenwerdens" can be rendered in English as acquiescence.

${ }^{36}$ Here our interpretation follows Peter Lassman, who says, "The concept of legitimacy refers to the acceptance of the validity of an order of rules," (Lassman, 2000, p. 87).

${ }^{37}$ Our view is that Weber's explanatory project does not invoke moral principles, but we think that his theoretical project has normative implications. We would agree with Sheldon Wolin, who argues that Weber's methodological innovations have normative implications that have not been fully appreciated (Wolin, 1981).
} 
domination in which obedience arises from a subject's regarding commands as valid -therefore they obey, rather than merely comply. A system of political domination, thus, lacks legitimacy whenever the obedience is not sustained by a belief in the validity of power.

\subsection{Weber's definition of a political community}

Having considered Weber's account of legitimate domination, it is worth examining his views on the nature of political communities. In Economy and Society he provides the following definition of a political community:

As a separate structure, a political community can be said to exist only if, and in so far as, a community constitutes more than an 'economic group'; or, in other words, in so far as it possesses value systems ordering matters other than the directly economic disposition of goods and services... In our terminology, a separate 'political' community is constituted where we find (1) a 'territory'; (2) the availability of physical force for its domination; and (3) social action which is not restricted exclusively to the satisfaction of common economic needs in the frame of a communal economy, but regulates more generally the interrelations of the inhabitants of the territory." (Weber, 1978, p. 902)

So, a political community involves three features: (1) territorial boundedness, (2) physical force, and (3) social cooperation that is ordered on the basis of value systems. Weber does not elaborate on what he means by "[the community] possesses value systems.” We suggest that it pertains to a set of norms and principles that bind a given community together (though they may remain entirely implicit). Only when there are such norms can interactions between the inhabitants be said to be regulated by social action, as opposed to mere economic cooperation. $^{38}$

${ }^{38}$ Remarkably, there is significant resonance with Aristotle's definition of political community. In Politics III, Aristotle indicates that a political community is to be defined as a partnership for the sake of ends that go beyond mutually useful cooperation, e.g. defense and trade (Aristotle, Pol 1280a31-1281a9) . 
Weber's definition of a political community has three implications for the idea of legitimate political domination. ${ }^{39}$ The first pertains to Weber's identification of violence as the characteristic means of politics. The claim that violence is characteristic does not imply that it is the primary or even the most common means that is used in this form of domination. Instead, it means that violence is uniquely essential as a means in the political context, in a way that it is not in other contexts. Because it is characteristic of a political community that violence is a key mechanism by which the system of obedience is maintained, the use of violence must be presupposed by any belief in the validity of power. That is, belief in the validity of power in the case of politics includes -- necessarily -- an accompanying belief in the justified use of violence. This is in contrast to other domains, in which the necessity of the use of physical force is normally not accepted. For example, in the educational context, a belief in the validity of power exercised by a teacher over students need not presuppose the use of violence to maintain order. ${ }^{40}$ Thus, in legitimate political domination, the belief in the validity of power includes a recognition that its claim on obedience is enforceable through violence.

Second, in non-political domination, the exercise of power is limited in scope: it pertains only to a particular domain of activity. For example, we accept the teacher's command when it regards our education but not our medical treatment, and vice versa for the doctor. Political domination, in contrast, is only limited by the scope of territory it claims to rule. Within that territory, it manifests as "in some respect the most important institutionalized system which can exist in that society," as Joseph Raz says. Its claim of

\footnotetext{
${ }^{39}$ For a discussion of similar ideas, see (Lassman, 2000, pp. 88-90). For an argument that legitimate domination must take a distinctive form when the political community is a modern democracy, see (Klein, 2017).

${ }^{40}$ At times, physical force is used in non-political contexts of domination, such as religion and childrearing. However, the necessity of violence is generally not part of the dominating relationship, which is evidenced by the fact that any justification of violence in that relationship relies on contingent and contextrelated reasons that appeal to principles other than the one related to the legitimacy of the domination. Another way to put this contrast is that using force is an essential part of politics, whereas it is not an essential part of religion or childrearing in the same way. For further discussion, see (Lassman, 2000, p. 90).
} 
authority is comprehensive (covers all forms of behavior), supreme (supercedes all other normative systems), and open (serves as a framework to sustain all other institutions that exist or may arise in its purview) (Raz, 2009, pp. 116-119). Since political domination treats the scope of authority as in principle unlimited, it requires unconditional obedience, no matter what the content of the command is, or its underlying rationale. ${ }^{41}$

Third, the belief in the validity of power is less visibly supported in the political sphere by a coincidence of interests between the ruler and the ruled, so it needs to be especially cultivated and promoted. To see this, notice that we normally accept our teachers' directives as valid because we see that there is an alignment of interests: it is in their interest to educate us and in our interest to learn. In the case of teacher-student domination, the student may readily see that desirable educational outcomes resulted from her obedience, and this helps to support her belief in the validity of the teacher's command. In contrast, the case of political domination requires more abstraction away from a subject's personal situation in order to see the benefits of domination. The benefits received through the exercise of political power are collective goods, neither chosen by an individual nor at her complete disposal. Often these diffuse goods are not evident or identifiable as a good to an individual (for instance, herd immunity). Since this weakens the link between obedience and detection of benefits, it is more difficult for subjects to ascertain -- even in favorable conditions -- whether the interests of rulers and ruled are aligned. For these reasons, obedience is not so easily maintained by perceived benefit as it is in non-political forms of domination. Accordingly, the belief in validity of power in political domination must be based on something other than the perceived coincidence of interests between the ruler and the ruled.

We think these three observations together imply that political domination has a greater need for legitimacy. Consider them altogether: the domination necessarily involves

\footnotetext{
${ }^{41}$ Even invoking the boundary between private and public is inadequate, for the political community claims the authority to determine where the private/public boundary is drawn.
} 
violence as a means; the domination demands unconditional obedience within a territory; and the domination lacks the clear perception of benefit by subjects. In light of these features, it is harder to establish and maintain domination in politics than in other domains, because the means are repugnant, the demand of obedience is total, and individuals cannot easily see how their interests are served. The need for legitimation is dramatically higher in these circumstances because the evident convergence of interests that might provide stable underpinning in other forms of domination is lacking, and, at the same time, the rulers need to establish a monopoly on the use of force and maintain an expectation of unlimited obedience. Moreover, the legitimation has to arise in a certain kind of way, making use of violence, but not relying on it too much. Later we will suggest that this legitimation must be closely linked to the value systems in a political community.

To review, in the first section we argued that Weber distinguishes between legitimate and illegitimate domination in terms of a belief in the validity of power. In this section we argued that, in the political domain, belief in the validity of power has a special character that makes it more difficult to attain, but also more crucial for sustaining the domination over time. We think that these elements of Weber furnish a basis for placing demands on the exercise of power. Whatever these demands are (and we will elaborate shortly), they do not include Williams's requirement that power not produce its own acceptance. Thus, it appears, Williams must reject Weber's account of legitimate political domination because it is an inadequate basis for criticizing power. But this rejection is too quick, we will now argue, for Weber has theoretical resources for criticizing the exercise of power.

\subsection{Political Normativity in Weber}


We will show Weber's potential for political normativity by identifying two dimensions of evaluation that are implicit in his writings about political power. The first dimension, which we call the ethic of rule, emerges from the interplay between the concepts of legitimate domination and political community; the second one, which Weber himself calls the ethic of responsibility, pertains to the relationship between means and ends in political action. We will argue that the two ethics, when taken together, show that Weber has a basis for developing a realist form of political normativity. ${ }^{42}$

We begin with the ethic of rule. Earlier we argued that, for Weber, political domination especially needs legitimacy. In order to secure this legitimacy, the exercise of power must be supported by a belief in its validity. Now we want to suggest that, since subjects must be motivated to obey without seeing a connection to personal benefit, their belief in the validity of power must be supported via some reference to values -- namely, those values that can be seen as ordering the political community. On this reading, political domination is legitimate when its exercise of power is viewed by subjects as corresponding to their values. When this link to values is combined with the observation that political domination especially needs to maintain legitimacy, this shows that rulers are under an imperative, a non-optional end that they must aim at: maintaining the perception among the ruled that power is being exercised according to their values. This imperative - which we call the ethic of rule -- provides a significant basis for criticizing the actions of those who exercise power.

\footnotetext{
${ }^{42}$ Since the reader may have concerns about our reliance on such different texts as Economy and Society and Politics as Vocation, it is worth making some historical remarks. Weber intended Part One of Economy and Society to be a conceptual clarification of Part Two, which was written earlier (between 1910 and 1914). Significant portions of Part One were revised between 1918 and 1920. Politics as a Vocation was delivered on 28 January 1919. These historical facts indicate that the two texts that we rely on received their final revisions in the same years. For further explanation, see Schluchter's introduction in Max Weber, Gesamtausgabe I/17, edited by Wolfgang J. Mommsen and Wolfgang Schluchter (Weber, 1992) and Roth's introduction to Max Weber, Economy and Society (Weber, 1978).
} 
In order to explain this further, we need to introduce the idea of there being a "congruence" between the mode of legitimation and the values of a specific political order. It is important, first, to distinguish these two things. We observed earlier that Weber's three modes of legitimation (rational-legal, traditional, and charismatic) refer to the types of belief in the validity of power. The value systems mentioned in the definition of the political community, in contrast, pertain to the ordering principles of a specific political community. The term translated as value systems is "Ordnungen". It is significant that Weber uses the plural instead of the singular, "Ordnung”. Since Weber is referring to a single political community, this indicates that any given political community is ordered according to multiple ordering principles (e.g. legal, economic, moral principles). The ordering principles for a given political community must fit with the mode of legitimation of that political community. However, there are multiple ways of realizing this fit. That is to say, two different sets of ordering principles displayed in an actual political community can be compatible with the same mode of legitimation. To give an example, both France and the United Kingdom display a rational-legal mode of legitimation; however, they display different ordering principles, e.g. presidential democracy versus parliamentary monarchy. Another example is German federalism versus Italian non-federalism, where the two different value systems are both consonant with a rational-legal type of legitimation. Not every value system can fit with every mode of legitimation. Nevertheless, there are different ways of sustaining the match between them.

According to this interpretation, legitimate domination rests on the congruence between what makes sense as a mode of legitimation (legal-rational, traditional or charismatic) and the underlying ordering principles of a given political community. Rulers are under an imperative to uphold this congruence, because they must maintain the belief in the validity of power. This imperative is the ethic of rule, in our view. Accordingly, rulers can 
be criticized for pursuing a political system in which the ordering principles do not match with the mode of legitimation. For example, in modern societies where legitimation depends on the rational-legal mode of legitimation, rulers should not promote and draw on patriarchal values in their exercise of power.

These grounds for criticism - the ethic of rule - gain even more force when they are combined with Weber's ethic of responsibility. Weber presents the "ethic of responsibility" alongside an "ethic of ultimate ends" in Politics as a Vocation (Weber, 1958, p. 120). ${ }^{43}$ The ethic of ultimate ends pertains to the pursuit of a principled aim and is not concerned with the means by which an actor pursues that aim. Accordingly, Weber thinks that the ethic of ultimate ends cannot provide sufficient guidance about what do to in politics. In contrast, the ethic of responsibility corresponds to fitting the means to the ends. In particular, it requires the politician to take into account that violence is the distinctive means of politics. The consequences of a political action -- which is always associated with the threat of violence, however faintly -- must be calculated accordingly. This is why the politician in particular cannot avoid being subject to the ethic of responsibility (Weber, 1958, pp. 123-126). This does not entail that the politician should not act in light of ideals and principles; indeed, at the end of the essay Weber indicates that only someone who combines the two ethics can be said to have a vocation for politics: "an ethic of ultimate ends and an ethic of responsibility are not absolute contrasts but rather supplements, which only in unison constitute a genuine man - a man who can have the "calling for politics"' (Weber, 1958, p. 127). Understood this way, the ethic of responsibility does not necessarily have a moral connotation, but it still provides a tool to critically evaluate the exercise of power. ${ }^{44}$

\footnotetext{
${ }^{43}$ Weber's idea of Gesinnungsethik has also been translated as the "ethic of ultimate ends", the "ethic of commitment", and the "ethic of principled conviction".

${ }^{44}$ Despite some parallels between the two vocation lectures, the content of Science as Vocation does not conflict with our interpretation. There the addressee is the academic scientist, whose duty is to practice nonevaluative research. For instance, Weber says that when the topic of democracy arises, politicians have a duty to express their opinion, while scientists are required to provide students with information without exercising any
} 
Interpreting the ethic of responsibility is controversial, but here we intend to make a more modest point. We argue that the ethic of responsibility - with its constraints on the politician's action - can be combined with the ethic of rule, in order to intensify the grounds for criticizing those who exercise power. In order to see the normative result of combining the two ethics, consider again the ingredients. According to the ethic of rule, one necessary end of rulers is to maintain widespread belief in the validity of power. This, in turn, requires rulers to maintain congruence between the mode of legitimation and the underlying values in a specific political community. Finally, according to the ethic of responsibility, those who exercise power are criticizable insofar as they misuse or abuse some means to that end namely, the end of maintaining congruence. In other words, they should not choose means that are inappropriate to that end, or that undermine that end. The combination of these elements implies that rulers are bound to employ power and violence as means only in ways that enhance what is required by the ethic of rule. Politicians still have some freedom in choosing their ends, but they are constrained in their use of coercion in pursuit of those ends. In other words, political actors have to use coercion in a way that is compatible with both the existing mode of legitimation and the value system displayed in their own political community.

Consequently, the combination of the two ethics implies that political domination is legitimate under two conditions. First, the politician's actions must fit with the mode of legitimation and with the underlying values, in such a way that their use of coercion maintains the congruence between these two levels. And second, the fit between the politician's actions and the two levels must be perceived as such by subjects. These conditions correspond to two ways in which political actors can be criticized: whenever they use coercion to pursue aims that conflict with either the mode of legitimation or the political 
community's values, and whenever they disregard maintaining the perception of the validity of power. For example, rulers who designate a certain religious confession to be the state religion, when half of the population avows other creeds, would be criticizable according to this framework. They would be seen as linking their claim to rightfully exercise power to a value system that is rejected by a significant portion of the community. However, it must be noticed that Weber's normative tools are not of help when rulers seek to change values or beliefs in order to produce a different congruence, e.g., one that would fit with the politician's actions. Since this way of ruling would violate Williams' critical theory principle, it would not be considered legitimate from his perspective.

Before we turn to Williams in the next section, it is worth highlighting exactly how this differs from Hobbes. While Hobbes equates legitimacy with political domination, for Weber it is possible to exercise political domination without securing political legitimacy -namely, by obtaining obedience based on fear or expediency. This is the sense in which, for Weber, there can be illegitimate political domination. In contrast, for Hobbes, legitimacy would be fully secured by the provision of security. Thus Weber's political realism can solve two problems with the Hobbesian position: it can show how the idea of political legitimacy is distinct from mere political subjection, and it can show how legitimacy, as a critical standard, is still conceptually related to political subjection. Weber's realist account of political legitimacy presents a compelling alternative to Hobbes, without resorting to moralism. On what basis is Williams entitled to reject it?

\subsection{Williams's Rejection of Weberian Realism}

Now that we have developed a Weberian form of political realism, we return to Williams's selective rejection of Weber. Williams follows Weber's lead in claiming that legitimacy is distinct from political domination. Williams straightforwardly adopts two 
insights from Weber. First, legitimacy is based on the beliefs of individual subjects, and, second, these beliefs play fundamental role in supporting or detracting from legitimacy without being constrained by principles of objective morality. Weber's approach is especially congenial because Williams wants to accommodate belief systems that do not descend from Enlightenment morality. The acceptance of the justification of power involved in Williams's Basic Legitimation Demand is intimately linked to the historical context in which subjects happen to evaluate power. In this respect, Williams and Weber are on the same page.

Still, Williams would not accept Weber's political realism, as we have constructed it. Remarkably, he does not deny that Weber has some scope for political normativity, even citing Weber's ethic of responsibility: "Max Weber in Politik als Beruf distinguished between an ethic of responsibility and an ethic of commitment, and it was his point that the former is still very much an ethic" (Williams, 2005, p. 72). ${ }^{45}$ However, from Williams's perspective, Weber's view is defective because it appears to allow for power to produce its own acceptance, thereby neglecting the critical theory principle. Recall that for Williams, power must not produce the acceptance that is meant to provide its legitimation. But according to Weber, power producing its own acceptance is consistent with legitimate political domination. Remarkably, the very phenomenon that Williams rules out is something that Weber is interested in explaining. Weber seeks to understand how systems of domination perpetuate themselves. His proposal is, we think, that they do so through sustaining the congruence between the mode of legitimation and the underlying values. Sustaining the congruence might involve using power to influence people's values. So Weber seems to

\footnotetext{
${ }^{45}$ Furthermore, at the end of the essay Williams speaks of Weber's ethic of responsibility approvingly but briefly: "I want a broader view of the content of politics, not confined to interests, together with a more realistic view of the powers, opportunities, and limitations of political actors, where all the considerations that bear on political action - both ideals and, for example, political survival - can come to one focus of decision... The ethic that relates to this is what Weber called Verantwortungsethik, the ethic of responsibility" (Williams, 2005, p. 12). He also invokes it with regard to the international promotion of human rights (Williams, 2005, pp. 72-73).
} 
permit - and even emphasize - exactly the sort of legitimation process that Williams wants to rule out by invoking the critical theory principle.

To see what is at stake, consider the following illustration. Imagine a political community where people affirm that the political community should be ordered according to democratic values. Suppose also that the leader promotes democracy, and it matches with the mode of legitimation (legal-rational legitimacy). However, the leader uses their power to influence people towards affirming democratic values, where they would not otherwise - say, due to traditional sentiments arising from ethnic and religious affiliations. The result is that they affirm democratic values and believe that the leader advances them. According to our interpretation of Weber's political realism, the conditions for legitimacy are fulfilled in this case. For the leader effectively upholds the congruence between the system of values and the mode of legitimation, and people correctly assess that the congruence is upheld. Williams, in contrast, would not view that domination as legitimate, because what matters is not only the congruence, but also how the congruence has been produced. When the rulers influence people towards affirming $X$ when they would not otherwise, they exploit their position in order to produce the acceptance of power, thereby violating the critical theory principle. This dynamic would undermine legitimacy for Williams but not for Weber.

Both Williams and Weber want to avoid moralism, and both think legitimacy depends on some kind of consistency between the exercise of power and people's values. However, while congruence and its appreciation by subjects is the whole story for Weber, Williams wants legitimacy to remain sensitive to the mechanisms that are used to bring about congruence and its appreciation. In this sense, Williams's normative account is stricter than Weber's. Nonetheless, Weber explains how there can be illegitimate politics without resorting to moralism, and therefore, he has as much claim to political realism as Williams does. Why is Williams not satisfied with Weber's more permissive realism? 
This observation links to our initial question, i.e. can power be self-legitimating?

Williams wants to answer negatively, by adding the constraints of the critical theory principle to the ones included in the notion of making sense. Weber's position is less strict, since power can achieve its own legitimacy by meeting two conditions: first, the ordering principles must be congruent with a mode of legitimation and, second, this congruence must be perceived as such by subjects. However, if the congruence has been produced by political power, Weber has nothing to offer in order to rule out this case. This comparison shows that Weber's account offers grounds on which to criticize power, yet those grounds are not strict enough to rule out the cases of self-legitimation that bother Williams.

\section{Implications for Political Realism}

Let us take stock. We began by observing that political realists -- including Williams - are in search of a critical standard of legitimacy that avoids moralism. Hobbes and Weber both offer possibilities, but Williams is not satisfied with either. He is not satisfied with the Hobbesian account because political subjection automatically entails legitimacy. He is not satisfied with Weber's account because it does not provide enough critical purchase. As we have seen, Williams is looking for a criterion for legitimacy that rules out power producing its own acceptance, either by influencing values or manipulating the beliefs of its subjects.

Once we look more closely at Weber, it becomes clear that he has the resources for developing a critical standard of legitimacy -- namely, the ethic of rule and the ethic of responsibility. And yet, it is clear that whatever critical purchase this involves, it would not be good enough for Williams. But why not? Answering this question for Williams will turn out to have broader implications for political realism.

Both Weber and Williams affirm at an abstract level that the exercise of political power stands in need of justification. However, they interpret this idea differently. Williams 
invokes the principle of might does not make right: "There is an essential difference between legitimate government and unmediated power: one of the few necessary truths about political right is that it is not merely might" (Williams, 2005, p. 135). ${ }^{46}$ Weber, for his part, also relies on the idea that organized forms of power have a need for self-justification. In Weber the justification is needed in order to maintain the legitimacy of the domination: "the continued exercise of every domination... always has the strongest need of self-justification through appealing to the principles of its legitimation" (Weber, 1978, p. 954). ${ }^{47}$ This is what leads to the allowance, in Weber, that power may secure its legitimacy through influencing the values or beliefs of its subjects.

This difference has implications for their understanding of legitimacy. Both have a realist account, and yet they reply differently to a fundamental question for realists, i.e. whether political power, in and of itself, can be self-legitimating. ${ }^{48}$ Weber and Williams would generally agree that it cannot, but they would disagree on interpreting this prohibition. To elaborate, for Weber, the prohibition on self-legitimating power means that it is not enough for power to declare that it is legitimate, or to secure compliance through coercion. Rather, people must believe that the exercise of power is valid. The prohibition on selflegitimating power, for Williams, means that power cannot use its influence -- which may be more or less coercive -- to produce acceptance.

\footnotetext{
${ }^{46}$ It is not clear what the other necessary truths are, but Williams seems to acknowledge other sources of sound reasoning that pertain to politics. 'While there are no doubt reasons for stopping warfare, these are not the same reasons, or related to politics in the same way, as reasons given by a claim for authority. In terms of rights, ...anyone over whom the state claims authority has a right to treatment justified by the claim of LEG' (Williams, 2005, p. 6).

${ }^{47}$ This remark is introduced with the following explanation. "We have encountered the problem of legitimacy already in our discussion of the legal order. Now we shall have to indicate its broader significance. For a domination, this kind of justification of its legitimacy is much more than a matter of theoretical or philosophical speculation; it rather constitutes the basis of very real differences in the empirical structure of domination. The reason for this fact lies in the generally observable need of any power, or even of any advantage of life, to justify itself" (Weber, 1978, pp. 953-954).

48 Though we cannot consider it here, it is possible that the disagreement about interpreting the claim would look different if we substituted 'coercion' or 'violence' for 'political power'.
} 
Who has the better interpretation of the claim that power cannot be self-legitimating? Williams cannot claim his view is more realist, as Weber is in a better position to show that he has entirely avoided a reliance on moralism, implicit or explicit. Weber also has the better claim to being "realistic" in terms of the actual dynamics of political power. Not only is Weber open to the possibility that power may change people's values and influence their beliefs, he places this dynamic at the center of his analysis of political legitimacy. As we argued earlier, a non-optional task of those wielding political power is to uphold the values that sustain order in a political community, namely, those values that are involved in maintaining a belief in the validity of power. So the question of influencing those values is always part of the equation, because it is an imperative of political domination that rulers maintain the acceptance of the exercise of power by subjects. In fact, one might even say that Weber constructs his analysis of legitimate political power in such a way that power is able to produce its own acceptance without violating the ethic of responsibility or ethic of rule. Therefore, it appears that Weber provides an interpretation of the claim that power cannot be self-legitimating that has stronger realist credentials than Williams. Williams might be inclined to say that if we did choose his interpretation, then we would lack a critical standard for assessing legitimacy. But this would be false, since Weber provides us with resources for criticizing the exercise of power: the ethic of rule and the ethic of responsibility.

Our remaining question is the following: is it possible for Williams to rule out the manipulation that Weber licenses while remaining realist? Williams's writings do not contain a definite reply to this question. He has three options, in our view. First, he could say that if political power is used to produce its own acceptance, then it is a wrongful use of political power. Essentially, the underlying claim would be that it is wrong to use power in order to influence values and beliefs. But it is moralistic to say that some uses of political power are wrongful as such. For, whatever is taken to supply the needed support for such a claim will 
end up relying on moral standards. Identifying something as a political wrong must have more force than implying merely that it is like a wrong move in a game, or an aesthetic error.

Second, Williams could say that power producing its own acceptance is ruled out by the very idea of political power. That is, when power produces its own acceptance, it is inconsistent with a relationship of political subjection. So, when rulers alter the beliefs of subjects in this way and to this end, then they are doing something criticizable - that is, it is criticizable in the specific sense that it is inconsistent with the political relationship. But this seems blatantly circular, because it simply stipulates what is meant to be proven. It claims that there is something inherent in the idea of political power that entails Williams's interpretation of legitimation, as opposed to that of Weber. It takes as its premise and conclusion that this interpretation is the critical standard that is to be applied to political power, due to the nature of political power. Taking such a stance does nothing to refute Weber's alternatives, which offer another critical standard that is to be applied to political power, one that is also said to be due to the nature of political power. While Williams is evidently unhappy with Weber's critical standard, his only hope of defending an alternative depends on explaining why his interpretation of "self-legitimating" is superior.

Still - and this is the third option - Williams might revisit the first political question. If Williams were to take this option, he would be saying that a violation of the critical theory principle shows that the first political question has not been solved. Insofar as Williams relies on the idea that the solution does not count as acceptable if it recreates the problem that politics is meant to solve, then he is under pressure to revert back to the Hobbesian form of realism, where an absence of legitimacy is equivalent to an absence of politics.

The only way for Williams to avoid collapsing into Weber and avoid collapsing into Hobbes is to find a plausible way of holding the following: the principle that power cannot produce its own acceptance is a requirement of legitimacy but not of political subjection. This 
seems very hard to do, if all the requirements of legitimacy must arise from the idea of political order. ${ }^{49}$ When it comes to making room for more realist standards of legitimacy, the space between Hobbes and Weber is vanishingly thin. Maybe the normativity in Weber, as we have constructed it, is the most that political realism can have.

At this point, we can draw a few conclusions. The comparison between Williams, Hobbes, and Weber helps us understand whether and how political realism can be regarded as a form of political normativity. In fact, there is a way of having a critical standard of legitimacy while remaining a realist: Weber's way. According to Weber, illegitimate politics can be identified and criticized, merely on the basis of ideas that emerge from what is distinctive about a political community. We think that the Weberian account we have developed has all the virtues that Williams seeks in a realist account of political legitimacy, so it is difficult for Williams to reject it on purely realist grounds.

Our analysis, then, has clarified the debate among political realists. It shows that it is virtually impossible to adjudicate between these three versions of realism on purely logical grounds. At an abstract level, they all claim to extract a legitimacy standard from a definition of political subjection, which, in turn, relies on claims about the nature of politics. These claims about the nature of politics function as though they were stipulations or axioms in the argument for each view, even though they have quite substantively different implications. So there is very little scope for adjudicating between versions of realism based on the quest for a purely realist standard of legitimacy, that is, one that is logically derived entirely from the nature of politics. To avoid dry and mechanical critique of their logical structure, these sorts of views have to be set alongside each other and compared on the basis of their substantive claims about the nature and the point of politics. If Williams's richer account cannot be

\footnotetext{
${ }^{49}$ For further elaboration on why Williams's proposal is unconvincing on this count, see (Leader Maynard and Worsnip, 2018). For an alternative proposal that overcomes this challenge, see (Greene, 2017; Greene, unpublished manuscript).
} 
defended without drawing on political moralism, then it seems that Weber's political realism stands at the outermost limit of realist normativity.

\section{Conclusion}

We began the paper by asking whether, as political realists claim, there is a special form of normativity that is unique to the political domain. We observed that this realist form of normativity must not be reducible to moral principles, but it also must avoid mere description. Hence, political realists must find a way to affirm the maxim that power cannot be self-legitimating. We explored these questions through an analysis of the realist proposal of Bernard Williams, arguing that he should be seen not only as a critic of moralism but also as a critic of realism. In particular, we assessed his implicit criticisms of the realist elements that can be found in Hobbes and Weber.

We showed that Williams's quest for a domain of political evaluation that is distinct from morality pushes him in a Hobbesian direction, leading him to define a political relationship as the securing of stable order. Then we showed how Williams's desire for a standard of legitimacy that goes beyond mere stable order leads him to depart from Hobbes. We argued that this departure then pushes Williams in the direction of Weber, because Weber's theory of legitimate domination can explain the difference between legitimate and illegitimate politics. But Williams chooses to depart from Weber as well, implying that Weber's theory of legitimate domination does not allow sufficient scope for critiquing power. But, as we showed, Weber's approach has ample resources for critiquing power through its ethic of rule and ethic of responsibility. We argued that if Williams is to sustain his departure from Weber while remaining a realist, he is under pressure to explain why power cannot produce its own acceptance through the influencing of beliefs and values. If Williams hopes to defend his interpretation of the prohibition on 'self-legitimating power' against that of 
Weber, he needs to show how violating the critical theory principle is inconsistent with the idea of politics. This will require, in the end, a substantive defense of his views on the nature of politics.

We conclude that if there is a viable form of political realism to be articulated other than the versions in Hobbes and Weber, Williams has not found it. Our analysis shows that his reasons for departing from Hobbes push him towards Weber, but his reasons for departing from Weber push him back towards Hobbes. At the same time, our investigation implies that a political normativity that is independent of morality is still possible, as long as we bear in mind the limits of its critical capacity. Ultimately, the comparison with Hobbes and Weber shows us how limited the options are -- for Williams, and for political realists in general.

\section{$\underline{\text { References }}$}

Aristotle. (1984). The Complete Works of Aristotle. Vol. 1 \& 2. (J. Barnes, Ed.). Princeton, NJ: Princeton University Press.

Bavister-Gould, A. (2011). Bernard Williams: Political Realism and the Limits of Legitimacy. European Journal of Philosophy, 21(4), 593-610.

Douglass, R. (2016). Hobbes and political realism. European Journal of Political Theory, 1474885116677481. https://doi.org/10.1177/1474885116677481

Geuss, R. (2008). Philosophy and Real Politics. Princeton, NJ: Princeton University Press.

Gledhill, J. (2012). Rawls and Realism. Social Theory and Practice, 38(1), 55-82.

Greene, A. (2017). Legitimacy without Liberalism: A Defense of Max Weber's Standard of Political Legitimacy. Analyse \& Kritik, 39(2), 295-323.

Greene, A. (unpublished manuscript). "The Promise of Political Realism." https://papers.ssrn.com/sol3/papers.cfm?abstract_id=3043529

Hall, E. (2013). The limits of Bernard William's critique of political moralism. Ethical Perspectives, 20(2), 217-243.

Hall, E. (2015). Bernard Williams and the Basic Legitimation Demand: A Defence. Political Studies, 63(2), 466-480.

Hobbes, T. (1983). De Cive: The Latin Version. (H. Warrender, Ed.). Oxford: Clarendon Press [1642].

Hobbes, T. (1991). Leviathan. (R. Tuck, Ed.). Cambridge University Press [1651].

Hobbes, T. (1998). Hobbes: On the Citizen. (R. Tuck \& M. Silverthorne, Eds.). Cambridge University Press.

Hoekstra, K. (2001). Tyrannus Rex vs. Leviathan. Pacific Philosophical Quarterly, 82, 420446.

Hoekstra, K. (2012). Hobbesian Equality. In Lloyd, S. A. (Ed.), Hobbes Today: Insights for the 21st Century (pp. 76-112). Cambridge: Cambridge University Press.

Jubb, R. (2015). Playing Kant at the Court of King Arthur. Political Studies, 63(4), 919-934. 
Klein, S. (2017). Between Charisma and Domination: On Max Weber's Critique of Democracy. The Journal of Politics, 79(1), 179-192.

Maynard, J. L., and Worsnip, A. (2018). "Is There a Distinctively Political Normativity?" Ethics, 128(4): 756-87.

Lassman, P. (2000). The Rule of Man over Man: Politics, Power and Legitimation. In Turner, S. (ed), Cambridge Companion to Weber. Cambridge: Cambridge University Press.

Loughlin, M. (2012). The political jurisprudence of Thomas Hobbes. In Dyzenhaus, D. and Poole, T. (Eds.), Hobbes and the Law. Cambridge: Cambridge University Press, pp. $5-21$.

McQueen, A. (2016). The Case for Kinship: Classical Realism and Political Realism. In Sleat, M. (Ed.), Politics Recovered: Essays on Realist Political Thought. New York: Columbia University Press.

McQueen, A. (2017). Political realism and the realist 'Tradition.' Critical Review of International Social and Political Philosophy, 20(3), 296-313.

Pettit, P. (2009). Made with Words: Hobbes on Language, Mind, and Politics. Princeton, NJ: Princeton University Press.

Raz, J. (2009). The Authority of Law: Essays on Law and Morality (2nd ed.). Oxford: Oxford University Press.

Read, J. H. (1991). Thomas Hobbes: Power in the State of Nature, Power in Civil Society. Polity, 23(4), 505-525.

Rossi, E. (2012). Justice, legitimacy and (normative) authority for political realists. Critical Review of International Social and Political Philosophy, 15(2), 149-164.

Rossi, E. and Sleat, M. (2014). Realism in Normative Political Theory. Philosophy Compass, 9(10), 689-701.

Skinner, Q. (2005). Hobbes on Representation. European Journal of Philosophy, 13(2), $155-$ 184.

Sleat, Matt. (2013). Liberal Realism: A Realist Theory of Liberal Politics. Oxford: Oxford University Press.

Sreedhar, S. (2010). Hobbes on Resistance: Defying the Leviathan. Cambridge: Cambridge University Press.

Waldron, J. (2013). Political Political Theory: An Inaugural Lecture. Journal of Political Philosophy, 21(1), 1-23.

Weber, M. (1958). Politics as a Vocation. In H. Gerth \& C. W. Mills (Trans.), From Max Weber: Essays in Sociology: International Library of Sociology A: Social Theory and Methodology. New York: Oxford University Press.

Weber, M. (1978). Economy and Society: An Outline of Interpretive Sociology. Berkeley: University of California Press.

Weber, M. (1992). Max Weber - Gesamtausgabe. (W. Mommsen \& W. Schluchter, Eds.). Tübingen: Mohr.

Weber, M. (2005). Wirtschaft und Gesellschaft: Wirtschaft und Gesellschaft: Grundriss der Verstehenden Soziologie. Frankfurt am Main: Zweitausendeins (Licensed from Melzer Verlag, Neu Isenburg).

Williams, B. (2005). In the Beginning was the Deed: Realism and Moralism in Political Argument. Princeton, NJ: Princeton University Press.

Williams, B. (2002). Truth and Truthfulness: An Essay in Genealogy. Princeton, NJ: Princeton University Press.

Wolin, S. (1981). Max Weber: Legitimation, Method, and the Politics of Theory. Political Theory, 9(3), 401-424. 